San Jose State University

SJSU ScholarWorks

Master's Theses

Master's Theses and Graduate Research

1994

\title{
Childhood maltreatment, combat-related posttraumatic stress disorder, and locus of control
}

Linda D. Fama

San Jose State University

Follow this and additional works at: https://scholarworks.sjsu.edu/etd_theses

\section{Recommended Citation}

Fama, Linda D., "Childhood maltreatment, combat-related posttraumatic stress disorder, and locus of control" (1994). Master's Theses. 749.

DOI: https://doi.org/10.31979/etd.pp93-ngpv

https://scholarworks.sjsu.edu/etd_theses/749

This Thesis is brought to you for free and open access by the Master's Theses and Graduate Research at SJSU ScholarWorks. It has been accepted for inclusion in Master's Theses by an authorized administrator of SJSU ScholarWorks. For more information, please contact scholarworks@sjsu.edu. 


\section{INFORMATION TO USERS}

This manuscript has been reproduced from the microfilm master. UMI films the text directly from the original or copy submitted. Thus, some thesis and dissertation copies are in typewriter face, while others may be from any type of computer printer.

The quality of this reproduction is dependent upon the quality of the copy submitted. Broken or indistinct print, colored or poor quality illustrations and photographs, print bleedthrough, substandard margins, and improper alignment can adversely affect reproduction.

In the unlikely. event that the author did not send UMI a complete manuscript and there are missing pages, these will be noted. Also, if unauthorized copyright material had to be removed, a note will indicate the deletion.

Oversize materials (e.g., maps, drawings, charts) are reproduced by sectioning the original, beginning at the upper left-hand corner and continuing from left to right in equal sections with small overlaps. Each original is also photographed in one exposure and is included in reduced form at the back of the book.

Photographs included in the original manuscript have been reproduced xerographically in this copy. Higher quality $6 " \mathrm{~m} 9$ " black and white photographic prints are available for any photographs or illustrations appearing in this copy for an additional charge. Contact UMI directly to order.

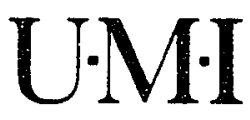

University Microfilms International

A Bell \& Howell information Company

300 North Zeeb Road. Ann Arbor. MI 48106-1346 USA

$313 / 761-4700 \quad 800 / 521-0600$ 
Order Number 1358173

Childhood maltreatment, combat-related posttraumatic stress disorder, and locus of control

Fama, Linda Domenica, M.S.

San Jose State University, 1994 


\title{
CHILDHOOD MALTREATMENT, COMBAT-RELATED POSTTRAUMATIC STRESS DISORDER, AND LOCUS OF CONTROL
}

\author{
A Thesis \\ Presented to \\ the Faculty of the Department of Psychology \\ San Jose State University
}

\author{
In Partial Fulfillment \\ of the Requirements for the Degree \\ Master of Science
}

by

Linda D. Fama

May, 1994 
(C) 1994

Linda D. Fama

ALL RIGHTS RESERVED 


\section{APPROVED FOR THE DEPARTMENT OF PSYCHOLOGY}
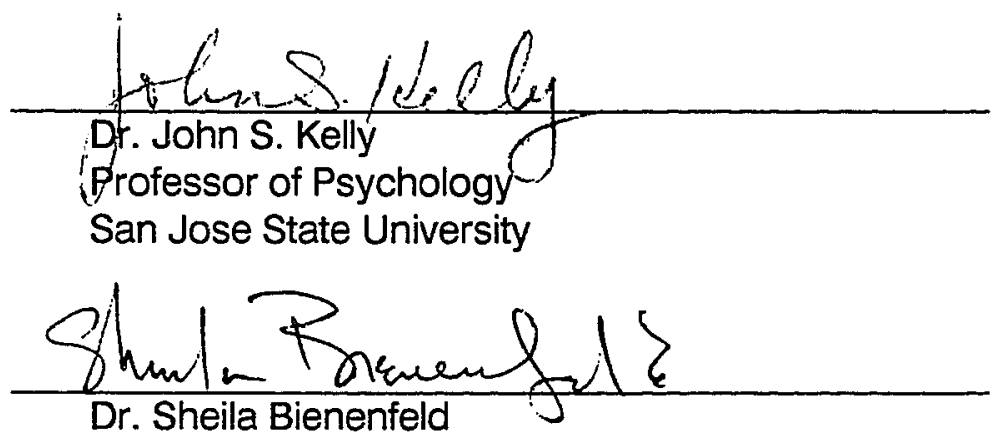

Associate Professor of Psychology

San Jose State University

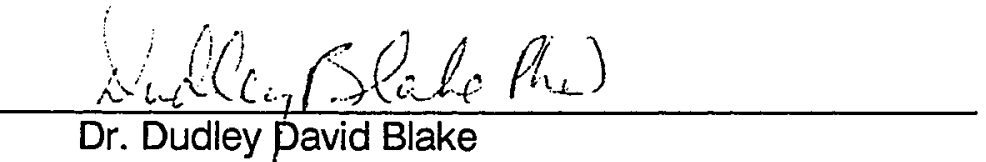

Associate Director of Behavioral Research

National Center for Posttraumatic Stress Disorder

Department of Veterans Affairs Medical Center

Palo Alto, CA

\section{APPROVED FOR THE UNIVERSITY}

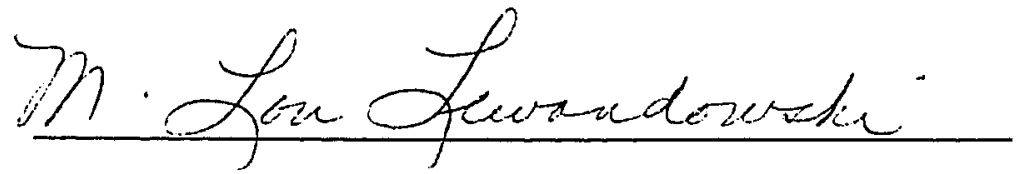




\section{ABSTRACT \\ CHILDHOOD MALTREATMENT, COMBAT-RELATED POSTTRAUMATIC STRESS DISORDER, AND LOCUS OF CONTROL}

by Linda D. Fama

The associations among childhood maltreatment (physical, emotional, and sexual abuse), combat-related posttraumatic stress disorder (PTSD), and locus of control were examined. A sample of 201 Vietnam veterans admitted to a PTSD program was studied. Using both self-report and clinician administered measures, information regarding combat-related PTSD symptomatology, locus of control, childhood maltreatment, and demographic variables was obtained. The veterans were divided into two groups: those who experienced $(n=112)$ and those who did not experience childhood maltreatment $(n=89)$. It was predicted that Vietnam combat veterans who were maltreated as children would experience more severe PTSD symptomatology and have a more external locus of control. Conversely, it was hypothesized that combat veterans not exposed to childhood maltreatment would experience less severe PTSD symptomatology and would possess a more internal locus of control. Although high rates of abuse were reported for the sample, no significant differences were found for the two groups on either locus of control or current PTSD symptomatology. 


\section{ACKNOWLEDGMENTS}

I would like to thank my committee members for their assistance during the past year on this project. I would especially like to thank Dudley Blake for all the time and support he has given me. I would also like to thank my husband, Michael, for respecting and understanding my academic goals. Lastly, I want to thank my family, especially my sister Rosemary, for all the support and encouragement I have received throughout the years. 


\section{TABLE OF CONTENTS}

SECTION

PAGE

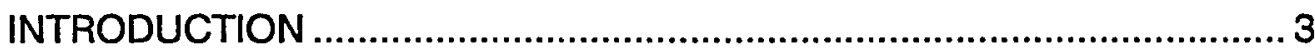

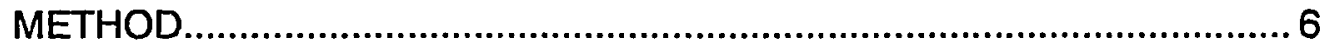

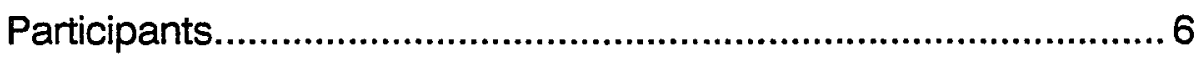

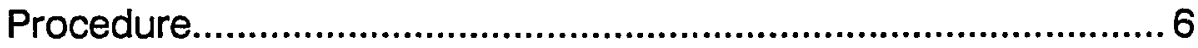

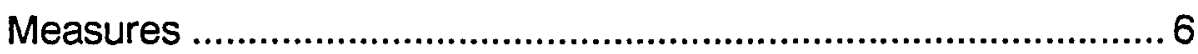

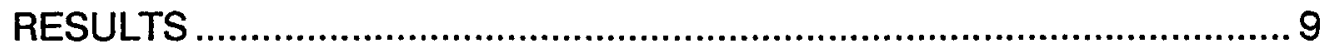

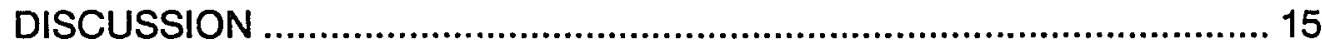

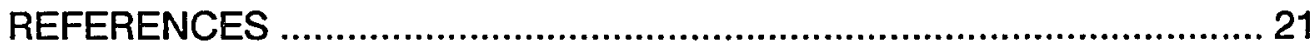

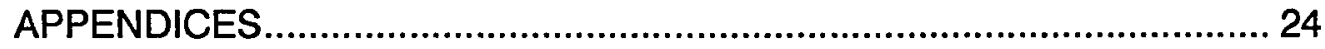

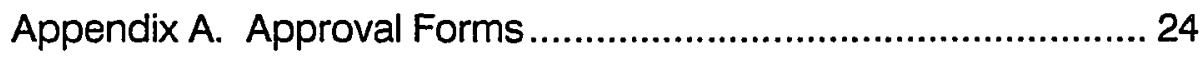

Appendix B. Basic Admission Data Sheet................................... 26 


\section{LIST OF TABLES}

TABLE PAGE

1. PTSD Inpatient Sample Demographics......................................... 10

2. PTSD Assessment and Locus of Control Data

on PTSD Inpatient Sample............................................................. 11 


\section{LIST OF FIGURES}

\section{FIGURE}

PAGE

1. Percentage of PTSD Inpatient Sample

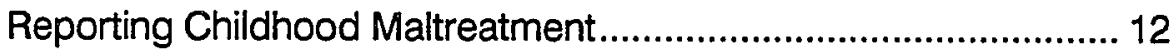

2. Family Suicidality and Substance Abuse

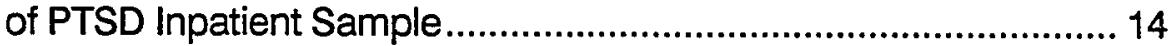

3. Mean Childhood and Adolescent Happiness

Ratings of PTSD Inpatient Sample Reporting

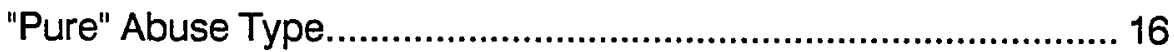




\author{
Childhood Maltreatment, \\ Combat-Related Posttraumatic Stress Disorder, \\ and \\ Locus of Control
}

Linda D. Fama

San Jose State University

Running head: TRAUMA AND LOCUS OF CONTROL

Footnotes

Requests for reprints should be sent to Linda D. Fama, Department of

Psychology, San Jose State University, San Jose, California 95192. 


\begin{abstract}
The associations among childhood maltreatment (physical, emotional, and sexual abuse), combat-related posttraumatic stress disorder (PTSD), and locus of control were examined. A sample of 201 Vietnam veterans admitted to a PTSD program was studied. Using both self-report and clinician administered measures, information regarding combat-related PTSD symptomatology, locus of control, childhood maltreatment, and demographic variables was obtained. The veterans were divided into two groups: those who experienced $(n=112)$ and those who did not experience childhood maltreatment $(n=89)$. It was predicted that Vietnam combat veterans who were maltreated as children would experience more severe PTSD symptomatology and have a more external locus of control. Conversely, it was hypothesized that combat veterans not exposed to childhood maltreatment would experience less severe PTSD symptomatology and would possess a more internal locus of control. Although high rates of abuse were reported for the sample, no significant differences were found for the two groups on either locus of control or current PTSD symptomatology.
\end{abstract}




\author{
Childhood Maltreatment, \\ Combat-Related Posttraumatic Stress Disorder, \\ and \\ Locus of Control
}

According to the Diagnostic and Statistical Manual of Mental Disorders-III-R (DSM-III-R; American Psychiatric Association, 1987), posttraumatic stress disorder (PTSD) is an anxiety disorder that develops following a psychologically distressing event that is outside the range of normal human experience. The characteristic symptoms involve reexperiencing the traumatic event, avoidance of stimuli associated with the event and/or numbing of responsiveness, and increased physiological arousal. Many Vietnam combat veterans have been known to suffer from symptoms of PTSD. In fact, the National Vietnam Veterans Readjustment Study estimated that 479,000 male Vietnam veterans suffer from PTSD (Kulka, Schlenger, Fairbank, Hough, Jordan, Marmar, and Weiss, 1988).

Why some veterans suffer from PTSD while others do not is unclear. Foy, Rueger, Sipprelle, and Carroll (1984) found that combat exposure and, to a lesser degree, military adjustment were more strongly associated with PTSD symptomatology than was premilitary adjustment. Solkoff, Gray, and Keill (1986) also found that preservice variables did not play a major role in the development of PTSD in a study of 100 Vietnam veterans. Instead, veterans with high combat exposure and negative homecoming experiences tended to have more PTSD symptomatology. Although many studies have found an association between combat exposure and PTSD, Casella and Motta (1990) found that not all Vietnam veterans with high combat exposure developed symptoms of PTSD. These investigators found that veterans not suffering from PTSD had lower Neuroticism 
and Psychoticism scores and were more likely than their PTSD counterparts to have shown an ability to provide structure to their Vietnam experience. In addition, PTSD veterans were found to be more external in their locus of control than non-PTSD veterans.

Locus of control orientation refers to the extent to which an individual perceives that events are controlled by internal or external factors. According to Rotter (1966), when a reinforcement is not entirely contingent upon an individual's action, it is often viewed as the result of fate or luck and the locus of control is perceived as being external. Alternatively, if an individual perceives that events are contingent upon his or her own behavior, the locus of control is believed to be internal. In Rotter's theory, a reinforcement acts to strengthen an expectancy that a particular behavior or event will be followed by that reinforcement in the future. Accordingly, the way individuals have been reinforced in the past determines the degree to which they possess either an external or internal control. Individuals with an external locus of control tend to report significantly more helplessness than those with an internal locus (Hiroto, 1974).

As it pertains to PTSD, individuals who have been exposed to situations over which they had little personal control, such as combat, are likely to possess a more external belief orientation. In a study by Solomon, Mikulincer, and Avitzur (1988) 262 Israeli soldiers suffering from PTSD were followed two and three years after the Lebanon war. In addition to finding a change in coping styles and perceived social support, intensity of PTSD symptoms declined, and locus of control became more internal for the sample after the third year.

Other factors have been examined to explain further why some veterans develop PTSD while others do not. Investigators have recently begun to look at 
the association between childhood maltreatment and combat-related PTSD in Vietnam veterans. Bremner, Southwick, Johnson, Yehuda, and Charney (1993), for example, found Vietnam veterans with PTSD to be significantly more likely to report childhood physical abuse than veterans without PTSD ( $26 \%$ versus $7 \%$ respectively). It was also found that the PTSD group had a significantly higher rate of total traumatic events before entering the military than the non-PTSD group. Also, Zaidi and Foy (1994) studied 22 male inpatient veterans using a standardized measure to assess history of childhood physical abuse and found a positive correlation between physical abuse and severity of combat-related PTSD. Of the 22 inpatients, $45 \%$ reported receiving severe physical punishment, $32 \%$ reported mild physical punishment, and $23 \%$ reported no physical punishment.

Childhood abuse and its long-term consequences have increasingly been studied during the past decade. Bryer, Nelson, Miller, and Krol (1987) found high rates of childhood physical and sexual abuse in a sampie of female psychiatric patients. Briere and Zaidi (1989) found significant associations among sexual molestation, sexual difficulties, history of suicidality, multiple psychiatric diagnoses (Axis I), and characterological traits or disorders (Axis II). However, many of the studies that focus on victimization consist largely of female subjects. Carmen, Rieker, and Mills (1984) studied 188 male and female psychiatric patients (65 males and 123 females) and 80 had histories of physical and/or sexual abuse. Although both males and females were used in the study, female patients were much more likely than males to have histories of abuse (53\% of the females versus $23 \%$ of the males).

The purpose of the present investigation is to evaluate the extent to which childhood maltreatment, combat-related PTSD, and external locus of control are 
all associated. Since previous research has focused on all female or mostly female groups, the present study explores childhood maltreatment as it pertains to male Vietnam combat veterans. It was predicted that Vietnam veterans who report childhood maltreatment experience more severe combat-related PTSD symptomatology and have a more external locus of control than their nonmaltreated counterparts.

Method

\section{Participants}

Two hundred and one male inpatients, admitted to a PTSD program between 1991-1993, served as participants for this study. All patients admitted to the program suffer from symptoms of combat-related PTSD and are judged to be in need of more extensive therapy than an outpatient program can provide. Although this PTSD program serves all war veterans, to enhance experimental control only Vietnam combat veterans who served between 1965-1973 were included. This service period was selected because these years reflect the period of most intense combat during the Vietnam War. The range of ages for this sample was $38-55$ years.

\section{Procedure}

Archival data were used for this study. As part of the admission process, an extensive psychological evaluation is conducted on each patient. Parts of this admission testing were used for this study. Only inpatients with completed admission folders were included as participants.

\section{Measures}

Information regarding each veteran's family of origin, personal history (e.g., history of family substance abuse, history of completed suicide in the 
veteran's family of origin, veteran's reported run away status, etc.) and childhood maltreatment (i.e., physical, sexual, and/or emotional abuse) was recorded using a basic admission data sheet (Appendix B). Participants also rated childhood and adolescence happiness scores on a scale ranging from 1 (never happy) to 5 (extremely happy). Because of changes in the method of data collection at the National Center for PTSD, $27 \%$ of the subjects had self-report admission data sheets while $67 \%$ were interviewed by clinicians. Information regarding PTSD symptomatology was gathered using the Clinician Administered PTSD Scale1(Blake, Weathers, Nagy, Kaloupek, Klauminzer, Charney, and Keane, 1990) and the Mississippi Scale for Combat-Related Posttraumatic Stress Disorder (Keane, Caddell, and Taylor, 1988). Each veteran's exposure to combat during Vietnam was assessed using the Combat Exposure Scale (Keane, Fairbank, Caddell, Zimering, Taylor, and Mora, 1989). Lastly, Locus of Control was measured with the Internal-External Locus of Control Scale (Rotter, 1966).

The Clinician Administered PTSD Scale-1 (CAPS-1). The CAPS-1 is administered in a one-to-one interview format by mental health professionals who have received extensive training with the instrument. The CAPS- 1 consists of 30 items, which include 17 items tapping core symptoms that constitute the Diagnostic and Statistical Manual of Mental Disorders-III-R diagnosis for PTSD and 8 items that assess associated symptoms of PTSD (e.g., survivor guilt, feelings of hopelessness, and disillusionment with authority). Each symptom is rated for its frequency and intensity. A one-month time frame is used for these ratings. Ratings for both frequency and intensity are made on 5 point scales ( 0 being the lowest to 4 the highest). The presence of a symptom is determined if the frequency of the symptom is rated as a 1 or greater and the intensity is rated a 2 
or greater. The CAPS-1 has demonstrated excellent interrater reliability, good internal consistency on each of the three PTSD subscales (reexperiencing, emotional numbing/avoidance, and hyperarousal), and adequate concurrent validity (Blake et al., 1990; Blake, Weathers, Nagy, Kaloupek, Gusman, Charney, and Keane, in press).

The Mississippi Scale for Combat Related PTSD (The Mississippi Scale). The Mississippi Scale is a 35-item self-report measure used to assess current PTSD symptomatology. The scale was derived from the PTSD criteria as listed in the Diagnostic and Statistical Manual of Mental Disorders-III-R (American Psychiatric Association, 1987). The statements on this measure are answered using a Likert scale (25 statements range from 1 [the lowest] to 5 [ the highest] while the remaining 10 are valenced in the opposite direction). The statements are summed and yield a measure of PTSD symptom severity ranging from 35-175. Analyses of internal consistency, factor-analytic studies, test-retest reliability, and discriminant validity data all indicate that the Mississippi Scale has acceptable psychometric properties (Keane et al., 1988). McFall, Smith, Mackay, and Tarver (1990) further corroborated the Mississippi Scale as a reliable and valid instrument for identifying PTSD symptomatology in Vietnam combat veterans. The Combat Exposure Scale (CES). The CES is a self-report measure which assesses wartime stressors to which individuals were subjected. Research has shown that this measure is both reliable and internally consistent (Keane et al. 1989). This measure contains seven Likert-type questions that assess the types of situations combatants experience during wartime. This measure is scored by summing the items (some items are given more weight than others). The CES yields a score ranging from 0 (no combat) to 41 (heavy combat). 
The Internal-External Locus of Control Scale (I-E Scale). The I-E Scale is a forced-choice test and contains 29 items, including 6 filler items. Subjects are asked to read pairs of alternative statements and to select the one that the individual believes to be more true. The items deal exclusively with the individual's beliefs about the world. The scale is scored by adding up the external statements, with scores ranging from 0 to 23. According to Rotter (1966), I-E Scale internal consistency estimates were relatively high, and test-retest reliability for a 1 month period was quite consistent in 2 different samples.

Results

Basic demographic and psychological assessment data are presented in Tables 1 and 2 respectively. According to the CAPS- 1 data, 95.5\% of the inpatient sample received a diagnosis of PTSD. The mean Combat Exposure Scale score suggests that the participants experienced a significant amount of war-time combat exposure. The mean Mississippi Scale score suggests that the participants suffered severe PTSD symptomatology (Table 2).

Chi-square tests were performed to assess for differences between the two forms of administration of the basic admission data sheet (self-report vs. interview). These tests did not reveal any statistically significant difference. Participants did not respond differently to the maltreatment questions regardless of whether they were posed in an interview or via self-report format.

The percentages of men maltreated as children were closely examined. While $15 \%$ of the sample reported sexual abuse, nearly half of the sample reported experiencing emotional abuse, and one-third of the sample reported having been physically abused (Figure 1).

The data were examined further along other parameters of family 
Table 1

PTSD Inpatient Sample Demographics a

\begin{tabular}{lrr} 
& Mean/Number & (SD)/Percent \\
\hline Age & 44.6 & $(2.9)$ \\
Years of Education & 13.4 & $(1.7)$ \\
& & \\
Marital Status & & \\
Married & 59 & 29.8 \\
Divorced & 81 & 40.9 \\
Separated & 32 & 16.2 \\
Single & 22 & 11.1 \\
Widowed & 4 & 2.0 \\
& & \\
Service Branch & & \\
Army & 131 & 65.5 \\
Navy & 20 & 10.0 \\
Marines & 42 & 21.0 \\
Air Force & 6 & 3.0 \\
Army \& Air Force & 1 & .5 \\
& & \\
Ethnicity & 150 & 75.4 \\
Caucasian & 21 & 10.6 \\
African American & 16 & 8.0 \\
Mexican American & 1 & .5 \\
Asian American & 6 & 3.0 \\
Spanish American & 4 & 2.0 \\
Native American & 1 & .5 \\
Filipino American & & \\
Run Away Status & 41 & 2.0 \\
Never & 37 & 18.9 \\
Once Only & & \\
Number of Times Not & & \\
Specified & & \\
More Than Once & & \\
\hline & & \\
an & & \\
\hline
\end{tabular}

$a_{\underline{n}}=201$, however, due to missing data, categories may not total 201 cases 
Table 2

PTSD Assessment and Locus of Control Data on PTSD Inpatient Sample a

Mean/Numbers

Percent/(SD)

$\begin{array}{lrr}\text { PTSD Diagnosis - CAPS-1 } & 192 & 95.5 \\ \text { NonPTSD Diagnosis - CAPS-1 } & 9 & 4.5 \\ \text { Combat Exposure Scale } & 28.6 & (7.3) \\ \text { Mississippi Scale } & 130.1 & (15.2) \\ \text { I-E Scale } & 12.5 & (4.8)\end{array}$

$a_{\underline{n}}=201$ 


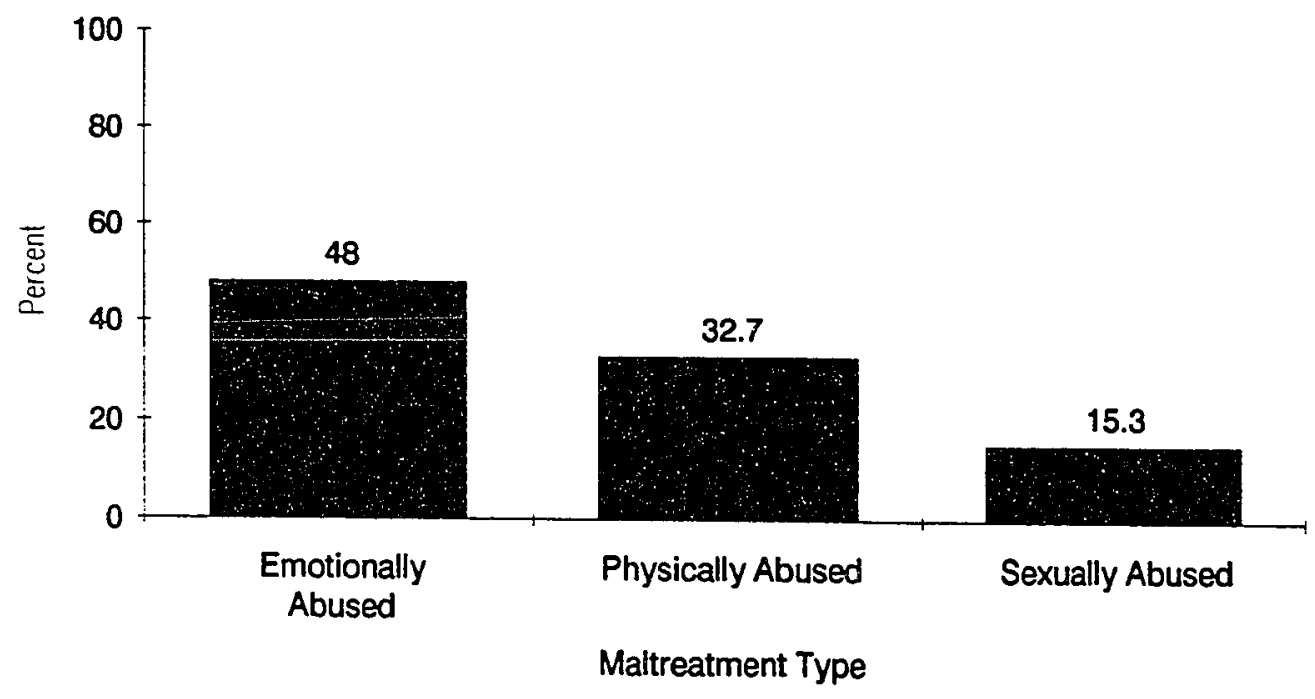

Figure 1. Percentage of PTSD Inpatient Sample Reporting Childhood Maltreatment $(\underline{n}=201)$ 
dysfunction. Nearly half of the sample reported alcohol abuse in their family of origin. While alcohol use was most prevalent, only $6.2 \%$ of the sample reported illicit drug abuse in their families. History of completed suicide in the veteran's family of origin (family suicidality) was also examined and was reported by almost $10 \%$ of the sample (Figure 2).

Correlation coefficients were calculated between several measures: the CAPS-1 and the Mississippi Scale, the Mississippi Scale and the I-E Scale, and the Mississippi Scale and the Combat Exposure Scale. Although the CAPS-1 and Mississippi Scale are both purported to assess PTSD symptomatology, pointbiserial correlations did not show a statistically significant correlation $(\mathrm{r} p \mathrm{pb}=-.0062, \mathrm{p}=.933)$. Using Pearson product-moment correlations, positive associations were found between the Mississippi Scale and the I-E Scale $(r=.16$, $\underline{p}<.05)$, and between the Mississippi Scale and the Combat Exposure Scale $(r=.29, p<.001)$.

Using analysis of variance the data were examined for differences between the childhood maltreated group and the nonmaltreated group on PTSD symptomatology, combat exposure, and locus of control. While no statistically significant differences were found for the groups, the CAPS-1 data suggested that PTSD symptomatology tended to be lower in patients reporting emotional abuse $(\mathrm{df}=1,185 ; \underline{F}=3.5 ; \underline{p}=.06)$.

Those veterans who were maltreated as children were analyzed further. "Pure" cases from each maltreatment type (i.e., subjects who endorsed only emotional, physical, or sexual abuse) were looked at separately to examine for differences among the measures of PTSD symptomatology, combat exposure, and locus of control. Analysis of variance revealed that abuse type was not 


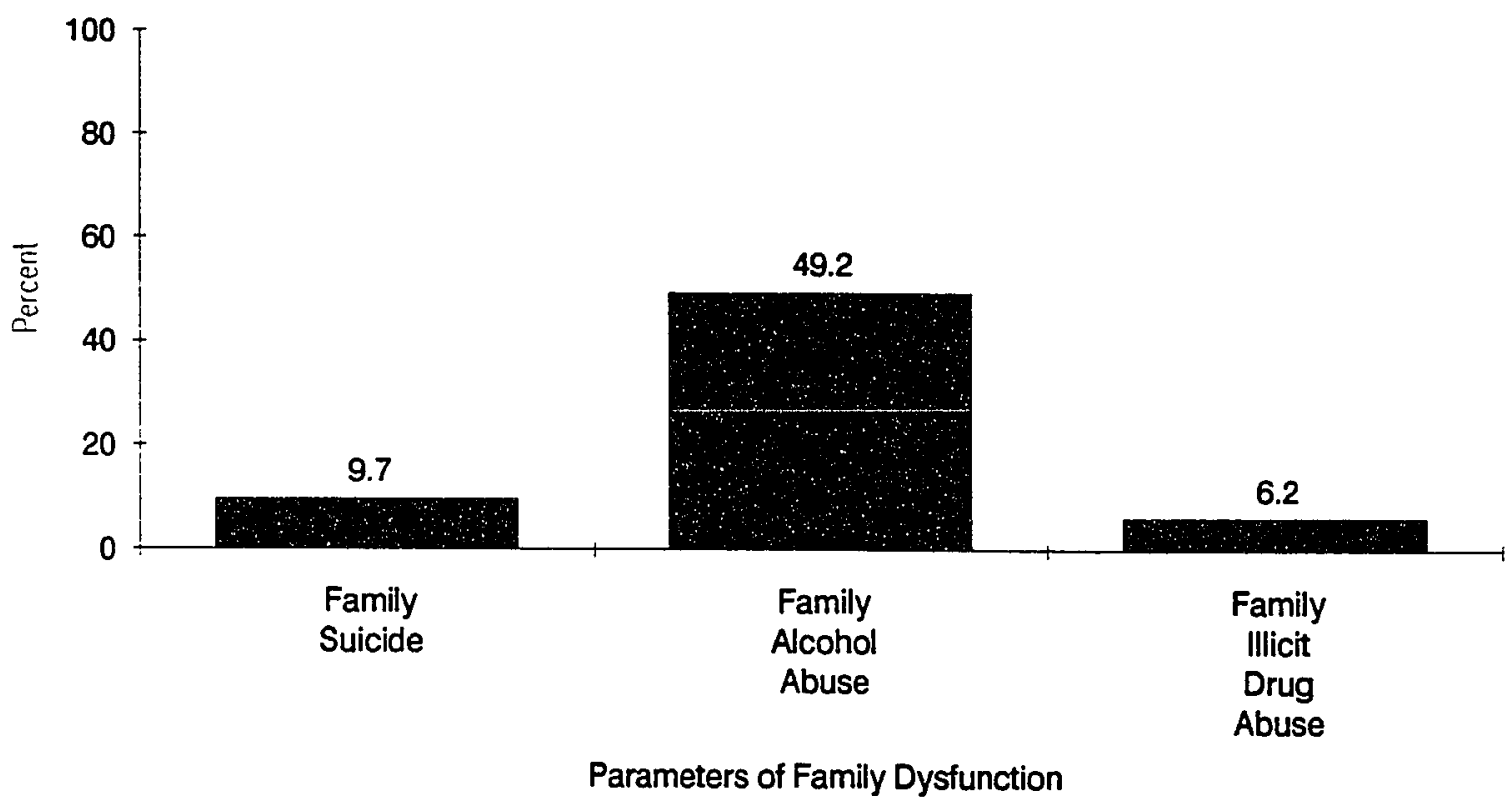

Figure 2. Family Suicidality and Substance Abuse of PTSD Inpatient Sample $(\underline{n}=201)$ 
significantly related to any of the assessment or demographic variables.

Multiple regression analysis found that CES scores, I-E Scale scores, and run away history predicted PTSD symptomatology as assessed by the Mississippi Scale. Looking more closely at the zero order correlations revealed that emotional and physical abuse were both negatively associated with reported happiness during childhood $(r=-.55$ and $r=-.49)$ and adolescence $(r=-.44$ and $\underline{r}=-.39$ ). However, sexual abuse was less strongly linked with happiness during childhood and adolescence $(r=-.21$ and $r=-.13)$. These associations are supported by viewing the mean happiness ratings provided by subjects in the "pure" emotional, physical, and sexual abuse categories (Figure 3). This figure generally shows emotionally abused subjects with the lowest and sexually abused subjects with the highest happiness ratings. Interestingly, and contrary to prediction, sexually abused veterans reported higher happiness ratings during adolescence as compared with emotionally and physically abused veterans.

When data related to family alcohol abuse were analyzed, it was found that this variable was moderately but significantly associated with physical $(r=.25$, $p<.001)$ and emotional abuse $(r=.26, p<.001)$, but not with sexual abuse $(\mathfrak{r}=-.06$; $\mathrm{p}=.22)$. Lastly, veterans run away status was correlated significantly with physical $(r=.30, p<.001)$ and emotional abuse $(r=.40, p<.001)$ but not with sexual abuse $(r=.03 ; p=.35)$.

\section{Discussion}

The results of this study show surprisingly high rates of childhood maltreatment in this sample of Vietnam combat veteran inpatients. Of the 201 Vietnam combat veterans that were studied, nearly $56 \%$ reported experiencing some form of childhood maltreatment (emotional, physical, and/or sexual abuse). 


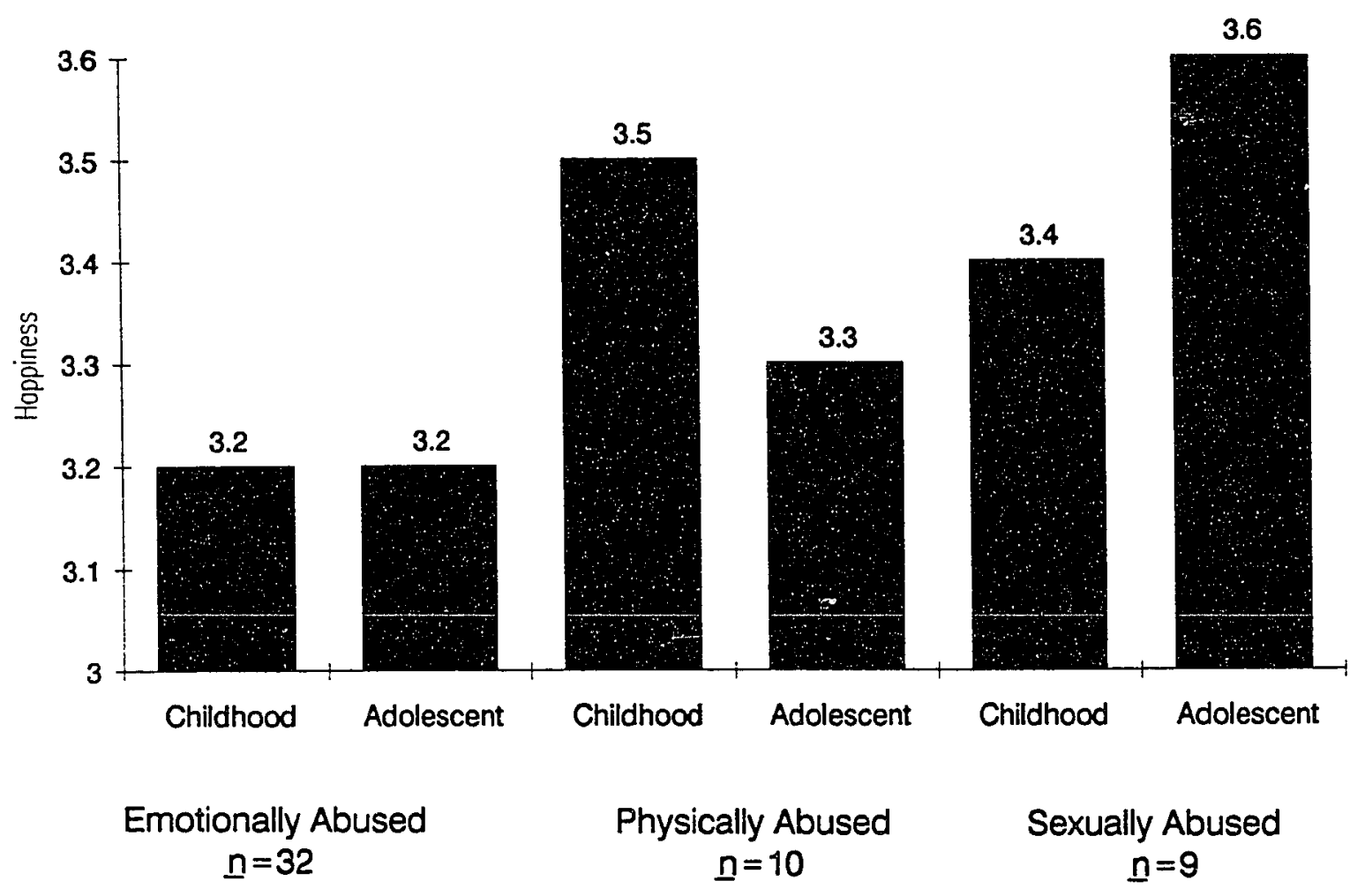

Figure 3. Mean Childhood and Adolescent Happiness Ratings of PTSD Inpatient Sample Reporting "Pure" Abuse Type 
The National Center on Child Abuse and Neglect estimates that $1.6 \%$ of children, under the age of 18, are abused and / or neglected annually (cited in Gelles and Cornell, 1990).

The prevalence of other family demographics also seemed higher than expected. Nearly $50 \%$ of the subjects reported family alcohol abuse and $10 \%$ reported that someone in their family of origin had committed suicide. These high rates of childhood abuse, family substance abuse, and exposure to suicide seem to be important variables and it appears that their relationship to combat-related PTSD needs further study.

The results did not support the hypothesis that Vietnam veterans who were maltreated as children experienced more severe combat-related PTSD and greater external locus of control. Three variables, however, were found to predict PTSD symptomatology: locus of control, combat exposure, and run away history. Of the three types of maltreatment, individuals who were sexually abused as children were expected to report the greatest PTSD symptomatology. It was believed that sexual victimization would have been the most troubling form of childhood maltreatment and the effects of that experience would carry over to the present. When sexual maltreatment was examined, however, greater PTSD rates were not found and those reporting childhood sexual abuse, in fact, rated childhood and adolescence happiness as being higher than those who were emotionally or physically maltreated. This finding could be related to the fact that this form of childhood maltreatment may be viewed by victims as non-punitive. Sexual abuse can sometimes be presented as a "special relationship" and it may be that this nonpunitive experience lead to less depressed ratings. 
Internal-External Locus of Control Scale scores were not statistically different between the maltreated and the nonmaltreated PTSD subjects. It was believed that those individuals maltreated as children would develop a more external locus of control because they experienced events (abuse) that were outside of their control. These feelings of being out of control would then be enhanced in combat. In war, individuals are constantly presented and involved in situations over which they have absolutely no control; combat experience would reinforce the ideation formed during childhood (i.e., that control is out of the individual's hands).

PTSD symptomatology, but not childhood maltreatment, was associated with an external locus of control. Individuals with an external locus have a tendency to see events as being determined by fate or luck. This finding may be explained by the way maltreatment is interpreted by children. Often children interpret actions of others as still being under their own personal control (e.g., physical abuse resulting from the child's misdeeds). It may be that these abused individuals viewed their childhood maltreatment as being under their control, while combat was out of their control.

Although childhood maltreatment did not predict current PTSD symptomatology, the high reporting of childhood maltreatment in the sample suggests a need for continued attention. Although childhood maltreatment has been the focus of much research, the role that it plays in the development of PTSD requires further examination. The prevalence of reported childhood maltreatment for this combat-related PTSD sample suggests that treatment for combat-related PTSD should focus upon premilitary as well as military stressors. 
Although childhood maltreatment was not positively associated with combat-related PTSD and a greater external locus of control, the measure used to assess childhood maltreatment may have contributed to the failure to find differences. Three questions on a demographic questionnaire were the only criteria used to examine childhood maltreatment. Each type of maltreatment (i.e., emotional, physical, and sexual) was assessed with one question each. It is likely that a full scale developed to assess childhood maltreatment would have produced more reliable and valid data in these areas (e.g., Kriegler, Blake, Schnurr, Bremner, Zaidi, and Krinsley (1991); Krinsley, Weathers, Young, Vielhauer, Kimerling, and Newman, (1993). A rating scale for maltreatment would not only answer the question of whether maltreatment occurred, but it would also yield a measure of the severity of the maltreatment. Berger, Knutson, Mehm, and Perkins (1988), for example, administered a questionnaire to a large university sample to assess childhood disciplinary experiences. In addition to disciplinary experiences, respondents were asked whether they had been "physically abused". Although over $12 \%$ of the sample described being injured by the discipline of their parents, only $3 \%$ of the sample labeled themselves as being physically abused as children. The tendency to mislabel childhood disciplinary experiences makes it necessary to use a full scale in order to assess accurately childhood maltreatment.

Since both the CAPS-1 and the Mississippi Scale assess PTSD symptomatology, it was surprising that these two measures did not correlate. The administration format for these measures (interview versus self-report) may help explain this finding. It could be that veterans respond differently to the questions depending on the manner in which the questions are presented. 
Although both measures assess PTSD, other differences between the measures can be seen upon closer examination. The CAPS-1 is closely linked to the symptoms of PTSD as listed in the DSM-III-R, while the Mississippi Scale seems to be less linked to the DSM-III-R criteria for the disorder. For example, the Mississippi Scale includes symptoms associated with PTSD (e.g., feelings of guilt) in diagnosing PTSD although those symptoms are not part of the DSM-III-R PTSD criteria. The CAPS-1 on the other hand, includes the associated symptoms of PTSD, but those symptoms are not used in determining an official DSM-III-R diagnosis of PTSD.

The Mississippi Scale - Combat Exposure Scale association found here is consistent with previous literature suggesting an etiological role for combat trauma in the development of PTSD symptoms. The positive association found between Mississippi Scale scores and I-E Scale scores suggests that Locus of Control also is an important factor in PTSD phenomenology; since the relationship at this point is correlational, inferences about causality can not be made with confidence.

The present study sheds important information about the association of combat-related PTSD and an external locus of control. Although more than half of the sample reported receiving some type of abuse as children, childhood maltreatment did not predict current PTSD symptomatology. The high prevalence of maltreatment may mean that childhood maltreatment and combat-related PTSD may be related in other ways not determined here. Although combat exposure plays an unquestionable role in the development of PTSD, the effects of maltreatment on PTSD still warrant further examination. 


\section{References}

American Psychiatric Association. (1987). Diagnostic and statistical manual of mental disorders (3rd ed., rev.). Washington, DC: Author.

Berger, A.M., Knutson, J.F., Mehm, J.G., \& Perkins, K.A. (1988). The self-report of punitive childhood experiences of young adults and adolescents. Child Abuse \& Neglect, 12, 251-262.

Blake, D.D., Weathers, F.W., Nagy, L.M., Kaloupek, D.G., Klauminzer, G., Charney, D.S., \& Keane, T.M. (1990). A clinician rating scale for assessing current and lifetime PTSD: The CAPS-1. The Behavior Therapist, 13, 187-188.

Blake, D.D., Weathers, F.W., Nagy, L.M., Kaloupek, D.G., Gusman, F.D., Charney, D.S., \& Keane, T.M. (in press). The development of a clinicianadministered PTSD scale. Journal of Traumatic Stress.

Bremner, J.D., Southwick, S.M., Johnson, D.R., Yehuda, R., \& Charney, D.S. (1993). Childhood physical abuse and combat-related posttraumatic stress disorder in Vietnam veterans. American Journal of Psychiatry, 150, 235-239.

Briere, J., \& Zaidi, L.Y. (1989). Sexual abuse histories and sequelae in female psychiatric emergency room patients. American Journal of Psychiatry, 146, 1602-1606.

Bryer, J.B., Nelson, B.A., Miller, J.B., \& Krol, P.A. (1987). Childhood sexual and physical abuse as factors in adult psychiatric illness. American Journal of Psychiatry, 144, 1426-1430.

Carmen, E.H., Rieker, P.P., \& Mills, T. (1984). Victims of violence and psychiatric illness. American Journal of Psychiatry, 141, 378-383.

Casella, L., \& Motta R.W. (1990). Comparison of characteristics of Vietnam veterans with and without posttraumatic stress disorder. Psychological Reports, 67, 595-605. 
Foy, D.W., Rueger, D.B., Sipprelle, R.C., \& Carroll, E.M. (1984). Etiology of posttraumatic stress disorder in Vietnam veterans: Analysis of premilitary, military, and combat exposure influences. Journal of Consulting and Clinical Psychology, 52, 79-87.

Gelles, R.J., \& Cornell, C.P. (1990). Intimate violence in families. Newbury Park, CA: Sage Publications.

Hiroto, D.S. (1974). Locus of control and learned helplessness. Journal of Experimental Psychology, 102, 187-193.

Keane, T.M., Caddell, J.M., Taylor, K.L. (1988). Mississippi scale for combatrelated posttraumatic stress disorder: Three studies in reliability and validity. Journal of Consulting and Clinical Psychology, 56, 85-90.

Keane, T.M., Fairbank, J.A., Caddell, J.M., Zimering, R.T., Taylor, K.L., \& Mora, C.A. (1989). Clinical evaluation of a measure to assess combat exposure. Psychological Assessment, 1, 53-55.

Kriegler, J.A., Blake, D.D., Schnurr, P.S., Bremner, J.D., Zaidi, L.Y., \& Krinsley, K. (October 1991). Developing a measure of early life trauma: The Early Trauma Interview (ETI), In J.D. Bremner (Chair), Childhood physical and sexual abuse: Assessment and neurobiological investigation. Symposium paper presented at the annual meeting of the Society for Traumatic Stress Studies, Washington, D.C.

Krinsley, K.E., Weathers, F.W., Young, L.S., Vielhauer, M., Kimerling, R., \& Newman, E. (October, 1993). Assessment of lifespan trauma: A multimethod integrative approach. Paper presented at the annual meeting of the Society of Traumatic Stress Studies, San Antonio, TX.

Kulka, R.A., Schlenger, W.E., Fairbank, J.A., Hough, R.L., Jordan, B.K., Marmar, C.R., \& Weiss, D.S. (1988). Contractual report of findings from the national Vietnam veterans readjustment study. Vol. 1: Executive summary, description of findings, and technical appendices. Research Triangle Park, NC: Research Triangle Institute. 
McFall, M.E., Smith, D.E., Mackay, P.W., \& Tarver, D.J. (1990). Reliability and validity of Mississippi scale for combat-related posttraumatic stress disorder. Psychological Assessment, 2, 114-121.

Rotter, J.B. (1966). Generalized expectancies for internal versus external control of reinforcement. Psychological Monographs: General and Applied, 80, 1-28.

Solkoff, N., Gray, P., \& Keill, S. (1986). Which Vietnam veterans develop posttraumatic stress disorder? Journal of Clinical Psychology, 42, 687-698.

Solomon, Z., Mikulincer,M., \& Avitzur,E. (1988). Coping, locus of control, social support, and combat-related posttraumatic stress disorder: A prospective study. Journal of Personality and Social Psychology, 55, 279-285.

Zaidi, L.Y., \& Foy, D.W. (1994). Childhood abuse experiences and combatrelated PTSD. Journal of Traumatic Stress, 7 , 33-42. 
Appendix A

\section{APPROVED BY THE MASTER'S THESIS COMMITTEE}
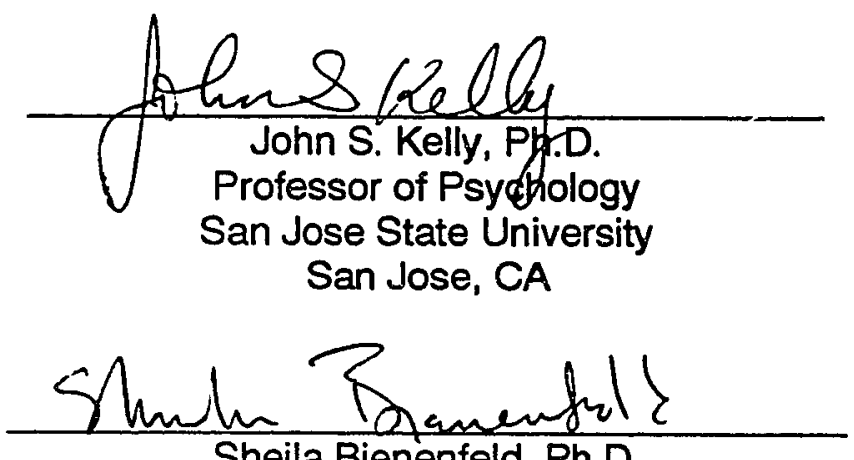

Sheila Bienenfeld, Ph.D.

Associate Professor of Psychology

San Jose State University

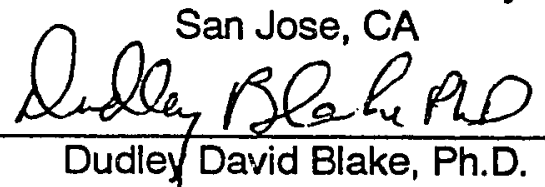

Associate Director of Behavioral Research

National Center for Posttraumatic Stress Disorder

Department of Veterans Affairs Medical Center

Palo Alto, CA

APPROVED BY THE DESIGN AND ANALYSIS COMMITTEE

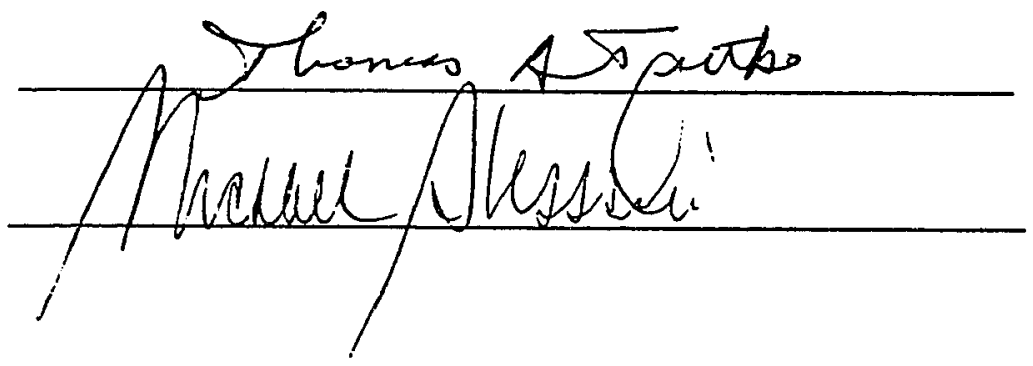


To: Linda Domenica Fama

2727 A Mauricia Ave.

Santa Clara, CA 95051

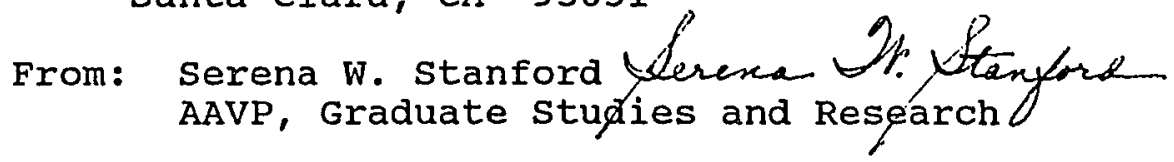

Date: October 7, 1993

The Human Subjects-Institutional Review Board has approved your request to use human subjects in the study entitled:

\section{"The Association Between Childhood Treatment, Combat-Related Posttramatic stree Disorder, and Locus of Control"}

This approval is contingent upon the subjects participating in your research project being appropriately protected from risk. This includes the protection of the anonymity of the subjects' identity when they participate in your research project, and with regard to any and all data that may be collected from the subjects. The Board's approval includes continued monitoring of your research by the Board to assure that the subjects are being adequately and properly protected from such risks. If at any time a subject becomes injured or complains of injury, you must notify Dr. Serena stanford immediately. Injury includes but is not limited to bodily harm, psychological trauma and release of potentially damaging personal information.

Please also be advised that each subject needs to be fully informed and aware that their participation in your research project is voluntary, and that he or she may withdraw from the project at any time. Further, a subject's participation, refusal to participate or withdrawal will not affect any services the subject is receiving or will receive at the institution in which the research is being conducted. If you have questions, please contact me at 408-924-2480.

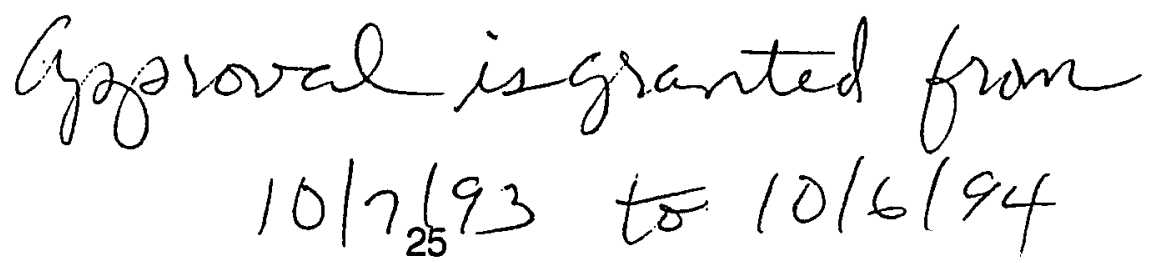




\section{Appendix B}

NATIONAL CENTER FOR PTSD

MENLO PARK DIVISION, VAMC PALO ALTO, CA

BASIC ADMISSION DATA SHEET

Social Worker:

Date:

1. Patient's name

2. DOB:

3. Age:

4. Soc. Sec. No.

5. Are you service connected? (circle one)

YES NO

Percent SC:

If service connected, for what?

6. Current marital status (circle one)
a) Married
d) Divorced
b) Living with Partner
e) Widowed
c) Separated
f) Never Married

7. Race or Ethnic Origin (circle one)
a) White or European American
f) Pacific Islander or Asian American
b) Black or African American
g) American Indian or Native American
c) Mexican American
h) Alaskan Native American
d) Spanish American
i) Other:
e) Hispanic American (Caribbean)
Language(s) spoken:

8. Who referred you to this program?

9. What problems were you having that led to your referral to this program? 
10. Please list all stressful events that are presently occurring in your life or were occurring in the year prior to your current admission.

\section{EDUCATION AND EMPLOYMENT HISTORY}

11. Schooling:
a) Completed Grade School or Less
e) Some College or Trade School
b) Some High School
f) Completed College
c) GED
g) Post Graduate Work
d) Completed High School
h) Post Graduate Degree:

Total years you attended school: (e.g., High-school graduate or GED = 12 years)

Any grades failed? /which History of truancy?

How would you rate your reading skills? (check one)

_ poor _ fair __ good _ _ery good _ excellent

12. Number of job(s) you have had since the military? (check one)

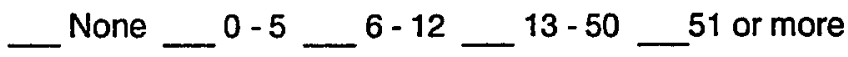

13. Are you currently employed (have a job waiting for you)? YES NO

If employed, name of employer:

Months/years in current position: 
Rate your present job satisfaction: (check one)

No satisfaction

High satisfaction

Low satisfaction

Very high satisfaction

Moderate satisfaction

If unemployed, number of months without work?

Number of jobs you have had in the last 2 years?

How many times in the last 2 years have you walked off jobs because you

got angry?

What is the longest continuous period of employment you have had at one job since the military? years __ months

14. What is your trade, professional, or basic job skill?

What has been your most satisfying job?

What is your current source(s) of income?

15. What is your current monthly income? (include social security compensation and disability benefits.) \$ a month

What was your total household income last year? (circle one)
a) Less than $\$ 10,000$
d) From $\$ 30,001$ to $\$ 40,000$
b) From $\$ 10,001-\$ 20,000$
e) From $\$ 40,001$ to $\$ 50,000$
c) From $\$ 20,001-\$ 30,000$
f) More than $\$ 50,001$

16. Are you and your family able to meet financial obligations while you are in the program?

$\begin{array}{ll}\text { YES } & \text { NO } \\ \text { YES } & \text { NO } \\ \text { YES } & \text { NO } \\ \text { YES } & \text { NO }\end{array}$

19. Will you be looking for housing?

YES

NO 
20. Are you currently seeking some form of monetary compensation? YES

If YES, circle the form(s) of compensation sought:
a) service connection
d) welfare
b) percentage upgrade
e) SSDI or SSI
c) workman's compensation
f) other:

21. Do you have durable power of attorney for health care?

YES

NO

\section{RELATIONSHIP HISTORY}

22. If you have been married or widowed, please answer the following:

\begin{tabular}{llll} 
& & Primary Reason & Present \\
Dates of Marriages & No. of & for Marriage & Ages of \\
From - To & Children & Dissolution & Children \\
\hline
\end{tabular}

a)

b)

c)

d)

23. List below the names and ages of all natural children. Also if your children do not live with you identify the adult with whom the child(ren) resides (e.g., "their mother") and estimate how frequently you talk to or exchange letters with the child(ren).

\begin{tabular}{lll} 
Names of children & $\begin{array}{l}\text { Adult with whom } \\
\text { the child resides }\end{array}$ & $\begin{array}{l}\text { Number of } \\
\text { contacts per month }\end{array}$ \\
\hline
\end{tabular}
a)
b)
c)
d)
e)
Are you under court order to make support payments?

$\begin{array}{lll}\text { Spouse } & \text { YES } & \text { NO } \\ \text { Child } & \text { YES } & \text { NO }\end{array}$
Are you behind in payments?
YES
NO
If YES, amount owed? 
24. List the natural, step, adopted and foster children for whom you have daily parenting responsibilities:

25. If living with a partner or spouse, are you concerned that your relationship is in serious trouble? $\quad$ YES NO UNCERTAIN

26. Are you and your spouse/partner currently involved in family or couple's counseling?

YES NO

If NO, do you think you and your spouse/partner need counseling?

27. Have you and your spouse/partner ever been involved in family or couple's counseling?

YES NO

28. Have any of your children ever been in counseling YES NO

If YES, which children:

For what problems:

29. Are any of your children having serious problems or problems that you would like to talk about?

YES NO

If YES, which children and what problems?

30. Is your family in support of your being in this program

YES NO

31. Is losing your temper a problem in your marriage or relationships?

YES NO

32. Do you have reason to be concerned that

Wife/Partner

YES NO

you might physically harm someone close

to you?

Children?

YES NO

Parents?

YES NO

33. Do you have reason to be concerned that you might emotionally harm someone close to you?

$\begin{array}{lll}\text { Wife/Partner? } & \text { YES } & \text { NO } \\ \text { Children? } & \text { YES } & \text { NO } \\ \text { Parents? } & \text { YES } & \text { NO }\end{array}$


34. Please rate the quality of relationship you now have with the individuals listed below (NOTE: in the case of deceased individuals, please write "dc" and rate the most recent 6 months spent while the person was alive):

$$
\begin{array}{ll}
1=\text { extremely satisfactory } & 4=\text { somewhat satisfactory } \\
2=\text { very satisfactory } & 5=\text { not satisfactory } \\
3=\text { satisfactory } &
\end{array}
$$

Spouse:

Partner:

Child 1:

Child 2 :

Child 3

Mother:

Father:
Sister 1:

Sister 2:

Sister 3:

Brother 1:

Brother 2:

Brother 3:

In-laws:

35. How many times per year do you talk with or see members of your family of origin?

Mother:

Father:
Brother 1:

Sister 1:
Brother 2:

Sister 2:
Brother 3:

Sister 3:

36. Estimate the number of friends with whom ...

1) You are very close (share your most personal thoughts and feelings)?

2) You are fairly close (discuss some personal problems)?

3) You are only on a first-name basis?

37. Do you feel you could use additional help around sexual issues, including relationships, sexual orientation, AIDS, etc. (circle)? YES

NO

Please check all that apply:

Sexual orientation: heterosexual

homosexual bisexual

HIV Status: positive negative suspected

HIV risk behavior since 1980: practiced unsafe sex IV drug abuser blood transfusion(s) Other 


\section{LEGAL HISTORY}

38. Have you ever been arrested since your discharge from the military? YES NO If you circled NO, skip remainder of this section and go to question \#42.

If YES, please list the following information:

$\begin{array}{clll}\begin{array}{l}\text { Number of } \\ \text { Arrests }\end{array} & \begin{array}{l}\text { Number of } \\ \text { Convictions }\end{array} & \begin{array}{l}\text { Time served } \\ \text { (months) }\end{array} & \begin{array}{l}\text { Time Served } \\ \text { (months) }\end{array}\end{array}$

a) Driving while under the influence

b) Driving without a license

c) Disorderly conduct

d) Assault

e) Possession of illegal weapons

f) Breaking \& entering

g) Theft

h) Drug sales or possession

i) Sexual assault

j) Manslaughter

k) Murder

1) Failure to pay alimony

m) Nonsupport of children

n) Vagrancy

o) Child molestation or abuse

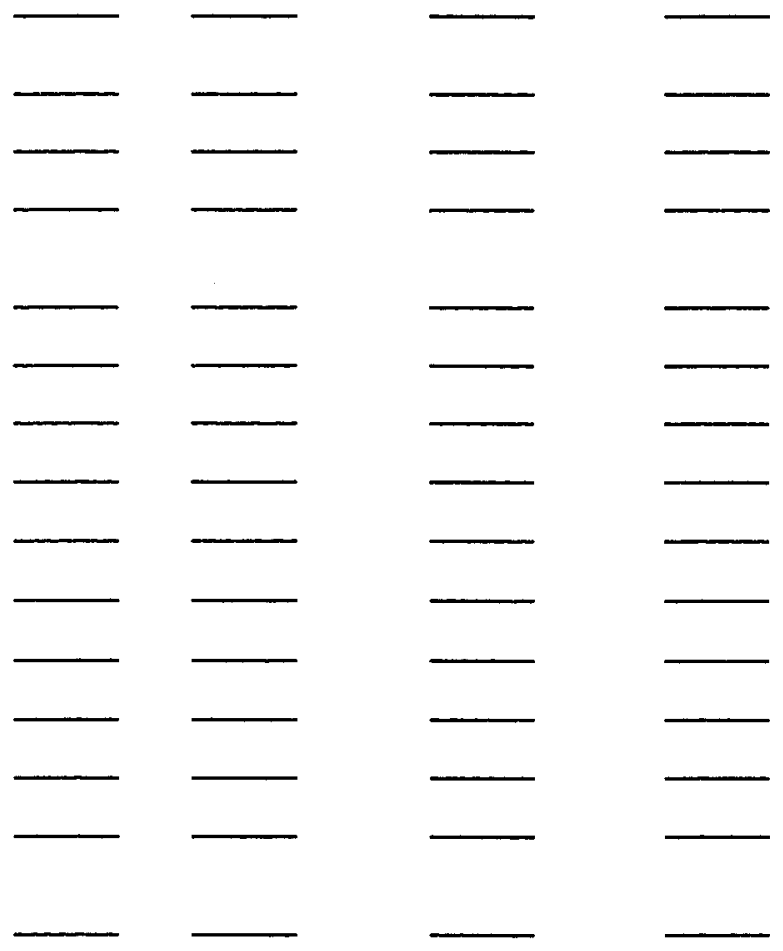

\section{TOTALS}

39. Beginning and ending date(s) you were in jail or prison (mo/yr) 1 .

2. 3.

40. Are you currently on probation or parole? If YES, was treatment a condition of your probation/parole? Name of Probation /Parole Officer:

Phone No. ( ) Offense:
5.

$\begin{array}{ll}\text { YES } & \text { NO } \\ \text { YES } & \text { NO }\end{array}$
State:
41. Are there any arrest warrants out for you at the present time? Do you have any upcoming court dates?
YES

No

YES 


\section{MILITARY SERVICE HISTORY}

42. War theater: Indicate below the war zone in which you served by placing a checkmark to the right of the appropriate war zone/era:
a. Vietnam
e. Panama
b. Korea
f. Southwest Asia
c. WWII
g. Saudi Arabia:
d. Grenada
h. Other:

43. Branch of service:(circle) Army Navy Air Force Marines OTHER:

44. How would you describe your military service? (please check one)

Mainly combat Mainly combat support Service support

45. Please list your dates of military service and your dates of service in the combat zone: Did you receive combat wounds? Were you a POW?

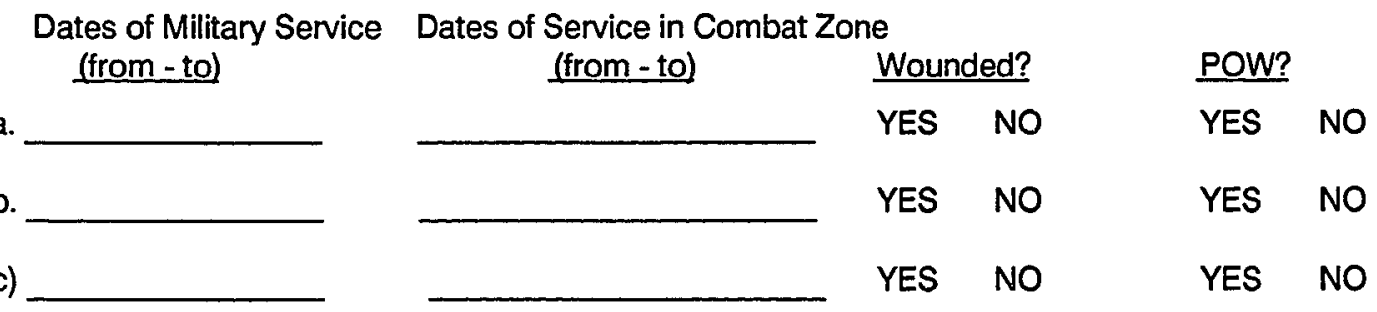

If ever wounded in combat zone, please describe briefly the nature of your wounds:

46. Unit/s to which you were assigned in the Combat Zone?

Division Regiment Battalion Company Corps Area

First Tour:

Second Tour:

Third Tour: 
47. Please check all of the combat experiences below which you encountered in the Combat Zone:

Served an artillery unit that fired on the enemy?

Flew in an aircraft over combat zone?

Stationed at a forward observation post?

Received incoming fire (small arms, rockets, mortars, artillery)?

Encountered mines or booby traps?

Was part of a Unit patrol that was ambushed?

Engaged with enemy in a firefight?

Saw Americans or allies killed and/or saw enemy or civilians killed?

Were wounded?

Received sniper or sapper fire?

Took part in an amphibious invasion?

On a ship that sailed through hostile waters?

On a ship that was attacked?

Were a medic or nurse? (medic/nurse in

field or hospital)

Decided who would receive lifesaving care?

Involved in the postmortem preparation and/or evacuation of bodies?

Sat with anyone dying from war-related causes?

Saw dead or dismembered bodies?

Received head injury without losing consciousness

Received head injury and lost consciousness (If YES indicate long

unconscious:

Repeated or constant direct exposure to defoliants (e.g., Agent Orange)

Participated in/witnessed atrocities?

48. List all the jobs that you had in the Combat Zone (e.g., RTO, platoon sgt., Corpsman, Recon, etc.):

List all weapons used in the Combat Zone: 
49. Number of disciplinary actions by tour of duty:

$\begin{array}{lll}\text { First Tour: } & \text { No. of Article 15's: } & \text { No. of Court Martials: } \\ \text { Second Tour: } & \text { No. of Article 15's: } & \text { No. of Court Martials: } \\ \text { Third Tour: } & \text { No. of Article 15's: } & \text { No. of Court Martials: }\end{array}$

50. List below all military decorations, citations, etc.

51. Type of military discharge(s)? (circle all that apply) Honorable General Bad Conduct Medical Other:

\section{MENTAL HEALTH SERVICES HISTORY}

52. Prior to your current inpatient treatment, had you ever received sevices from a mental health professional (Counselor, Social Worker, Psychologist, Psychiatrist, or Clergy) for an emotional or psychiatric problem (for example, nerves, depression anxiety)? YES NO If NO, skip to question \#62.

If YES, during what period(s) of your life did you receive these services?

Pre- Military Military Post-Military

53. What type of mental health professional(s) have you seen? (please check all that apply):

$\begin{array}{lll}\text { Counselor } & \text { Social Worker } & \text { Psychologist } \\ \text { Psychiatrist } & \text { Clergy } & \text { Vet Center Counselor } \\ \text { other: } & & \end{array}$

54. Was the mental health professional(s) connected with the VA? YES NO

55. What is the longest period of time you have worked with one therapist as an outpatient? years months 
56. Have you ever been hospitalized for an emotional problem?

YES NO

If YES, please list hospital, dates of and reasons for admission (e.g., suicide attempts, alcoholism)

$\begin{array}{ccc}\text { Name of Hospital } & \begin{array}{c}\text { Dates of Hospitalization } \\ \text { From - To }\end{array} & \begin{array}{c}\text { Type of } \\ \text { Discharge }\end{array}\end{array}$

a)

b)

c)

Hospitalization(s) for a total of

years and months.

57. Have you ever received treatment through a VA outpatient clinic? YES NO If YES, please indicate which VA Medical Center(s), estimate the total number of sessions (for each), and give approximate years/months this treatment began and ended:
$\underline{\text { VA Clinic }}$
\# Sessions
Beginning/End Dates

a)

b)

c)

58. Have you ever received treatment through a Vet Center? YES NO

If YES, please indicate which Vet Center(s), estimate the total number of sessions (for each), and give approximate years/months this treatment began and ended:
Vet Center
\# Sessions
Beginning/End Dates

a)

b)

c) 
59. Generally, for what problem(s) have you sought help? (please check all that apply):

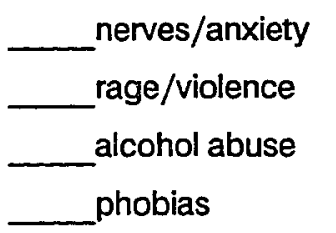
___ depression suicidal thoughts/attempts panic other: mania drug abuse hallucinations/delusions

60. What kind(s) of treatment have you received? (please check all that apply):

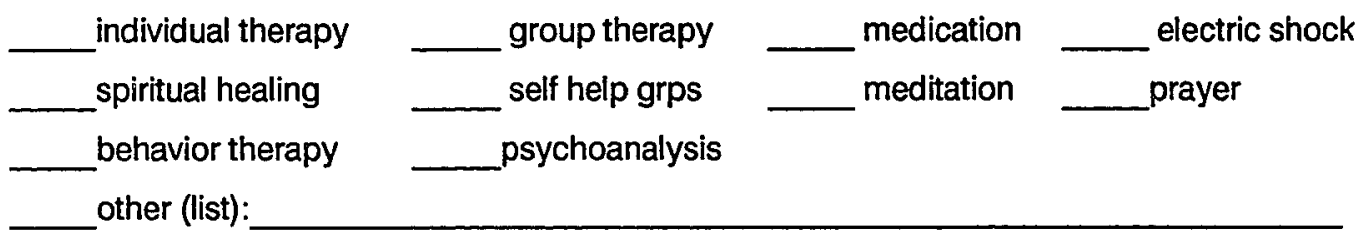

What type of treatment(s) seemed to help most?

61. Have you ever been prescribed medications for emotional or psychiatric reasons? (e.g., tranquilizers, sedatives, etc.)

If YES, for what?

Name of medications?

When $(\mathrm{mo} / \mathrm{yr}$ to $\mathrm{mo} / \mathrm{yr})$ ?

Are you currently taking medications? YES NO If YES, what kind?

62. Have you ever considered and/or attempted suicide?

YES NO

Dates of all attempts (mo/yr)

\section{FAMILY HISTORY}

63. Where were you born?

Were you an adoped or foster child?

Where were you raised?

Number of moves before completing highschool? 
64. How many brothers do you have? What are their ages? How many sisters do you have? What are their ages?

In what order were you born (e.g., 1st, 2nd, etc.):

Were you named after anyone in the family? YES NO Who?

65. Did your parents get divorced/separated before you were 18?

YES NO If YES, how old were you when this happened?

With whom did you live after the divorce/separation?

How many times did your custodial parent remarry?

66. Has anyone in your family been hospitalized for emotional or psychiatric reasons? YES NO Has anyone in you family attempted suicide?

YES NO

Has anyone in your family committed suicide?

YES NO

When you were growing up did either one of your parents abuse drugs?

YES NO

When you were growing up did either one of your parents abuse alcohol?

YES NO

When you were growing up did you experience any physical/mental abuse?

YES NO

67. While growing up, did you receive excessive punishment (punishment that resulted in bruises, bleeding, burns, broken bones, etc.) by your mother, father, or other primary caretaker(s)?

YES NO

68. While growing up, were you often ridiculed, shouted at, criticized or othenwise emotionally abused by your mother, father, or other primary caretaker(s)?

69. While growing up, were you ever sexually abused or sexually molested? If YES, who was the abuser (e.g., uncle, father) and between what ages were you when you were abused?

70. While growing up, did you ever witness your brother(s)/sister(s) being:

Physically abused?

Emotionally abused?

Sexually abused?

$\begin{array}{ll}\text { YES } & \text { NO } \\ \text { YES } & \text { NO } \\ \text { YES } & \text { NO }\end{array}$


71. Did you ever run away from home?

YES

NO If YES, at what age(s) How many times?

Why?

72. Rate your happiness during childhood and adolescence using the following scale:

CHILDHOOD (0 - 12 years old)

1

2

3

4

5

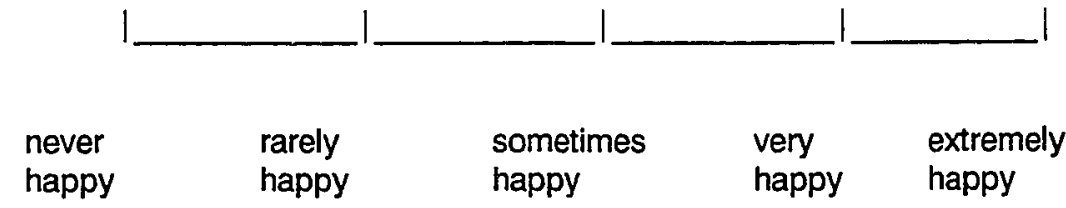

ADOLESCENCE (ages 13 to military service)

1

2

3

4

5

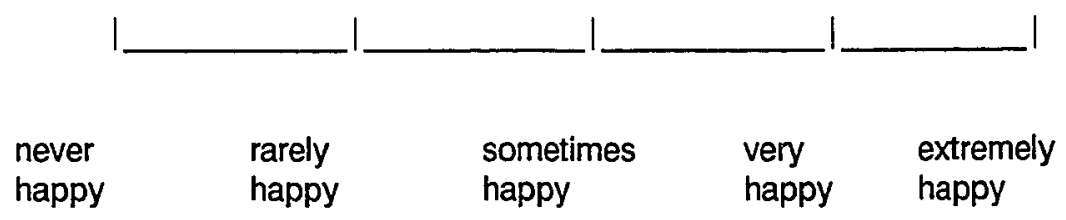

73. Did your father or mother (circle which one) sene in the military? Father Mother

74. Did your father or mother (circle which one) serve in combat? Father Mother If YES, list war:

Was he listed as a POW or MIA? YES NO

75. Were you involved in any serious accidents or exposed to other stressful events while growing up?

If YES, briefly what were the accidents or events? 


\section{DRUG AND/OR ALCOHOL USE}

76. Have you ever felt you had a problem with alcohol or drug use? YES NO
If Yes,
1) Drug
2) Alcohol
3) Both

77. Which, if any of the following have you used in the past 6 months?
1) Alcohol
5) Hallucinogenic
2) Sleeping pills
6) Amphetamines/stimulants
3) Tranquilizers/sedatives
7) Barbiturates
4) Cocaine
8) Opioids
5) Marijuana
9) Other

78. Have you ever sought treatment for alcohol abuse?

$\begin{array}{ll}\text { 1) YES } & \text { 2) NO } \\ \text { 1) YES } & \text { 2) NO } \\ \text { 1) YES } & \text { 2) NO } \\ \text { 1) YES } & \text { 2) NO }\end{array}$

79. Have you ever sought treatment for drug abuse?

$\begin{array}{ll}\text { 1) YES } & \text { 2) NO }\end{array}$
1) Before military service
1) YES
2) NO
2) During military service
1) YES
2) $\mathrm{NO}$
3) After military service
1) YES
2) NO

If YES to 78/79, complete the following graph on the next page, sign and date:

If NO, sign and date the last page 


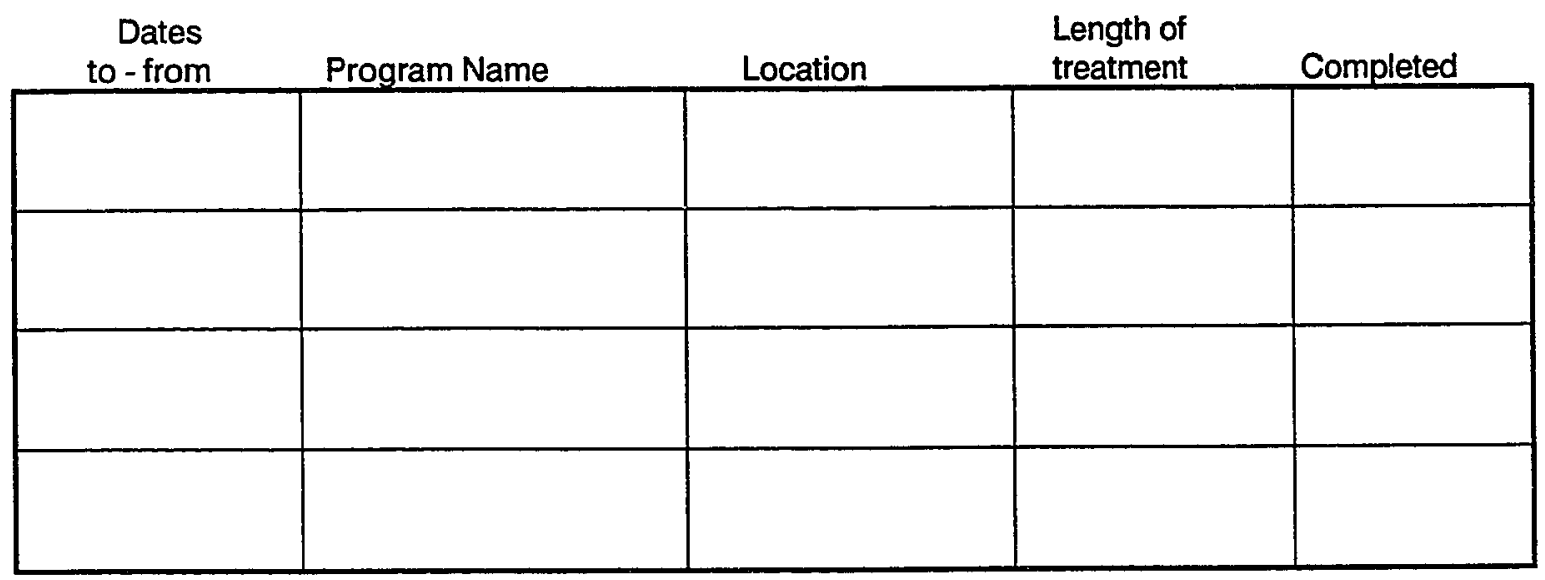

Social Worker: Date: 